\title{
PHILOLOGY
}

\section{SOCIO-CULTURAL FACTORS IN THE FORMATION OF ENGLISH ANTHROPONYMIC NOMINATIONS}

\author{
PhD in Philology, Oksana Nikolenko \\ Ukraine, Kyiv, Taras Shevchenko National University of Kyiv, \\ Institute of Philology, English for Mathematical Departments \\ DOI: https://doi.org/10.31435/rsglobal_wos/31082019/6658
}

\section{ARTICLE INFO}

Received: 25 June 2019

Accepted: 16 August 2019

Published: 31 August 2019

\section{KEYWORDS}

socio-cultural, anthroponym, neologism, semantic meaning, metaphor, telescoping.

\begin{abstract}
At the beginning of the 21 st century innovative language processes at the lexico-semantic level are the most active in the fields that are caused by such macrosocial factors as the information revolution and informationrelated activities in all human societies. The article describes the extralinguistic factors that influence the formation of anthroponymic nominations in the modern English language, focusing on different word formation processes and demonstrates the contiguous interaction between language and society.
\end{abstract}

Citation: Oksana Nikolenko. (2019) Socio-Cultural Factors in the Formation of English Anthroponymic Nominations. International Academy Journal Web of Scholar. 8(38), Vol.2. doi: 10.31435/rsglobal_wos/31082019/6658

Copyright: (C) 2019 Oksana Nikolenko. This is an open-access article distributed under the terms of the Creative Commons Attribution License (CC BY). The use, distribution or reproduction in other forums is permitted, provided the original author(s) or licensor are credited and that the original publication in this journal is cited, in accordance with accepted academic practice. No use, distribution or reproduction is permitted which does not comply with these terms.

Вступ. У сучасних лінгвістичних дослідженнях неабиякий інтерес як об'єкт номінації становить людина та різноманітні об'єднання індивідів [6, с. 25]. Однією з причин такої уваги є те, “що, міняючи ролі, наслідуючи різні моделі поведінки, реалізуючи певні дії, людина в своїх різноспрямованих проявах стає референтом багатьох функціональних, реляційних та інших імен" [1, с. 179]. Категорія найменування особи охоплює різноманітні значення та характеризує людину як носія суспільних (соціально-професійних, національних) відносин та як істоту біологічну із властивими їй якостями, ознаками, особливостями, які виступають у ній ще в більш диференційованому вигляді [1].

Якщо розглядати єдине семантичне значення особи як засіб відбиття та зберігання знань про властивості та діяльність людини, то назви особи належать до ядерної лексики, що зберігає у своїх значеннях «знання першого ешелону та представлена сектором повного збігу при накладанні однієї на іншу концептуальної та мовної картини світу» [8, с. 22].

Серед факторів, відображуваних в імені людини і тісно пов'язаних з їі життєдіяльністю, слід виділити такі: географічне середовище, біологічні характеристики, культура етносу, суспільне життя (класова і статусна належність, належність до соціальних інститутів, професійних асоціацій).

Мета дослідження - дослідити соціокультурні фактори, що впливають на створення нових антропонімічних найменувань в англійській мові та описати тенденції розвитку словотворчих засобів і способів словотворення.

Результати дослідження. В англійській мові $є$ велика кількість найменувань, що позначають соціальний статус комунікантів. Соціальний статус людини являє собою семантичну категорію, змістом якої $є$ вираження нерівності між учасниками спілкування, а планом вираження - система лінгвістичних і паралінгвістичних індексів, що передбачають 
підкреслення свого статусу і статусу партнера та засоби вираження свого ставлення до різниці між своїм станом і станом партнера [5, с. 330].

Сучасне англомовне суспільство складається з різних соціальних спільнот, груп, що посідають різні місця в системі соціальної нерівності, в диференціації населення суспільства за такими показниками, як влада, власність, прибуток та ін. Британське суспільство вважається класово нерівним і поділяється на дві категорії: $U$ (upper class) і non-U (all the rest) [2]. Для позначення представників вищих класів суспільства використовують численні оцінні номінації: higbred, highborn, illuminati, pick, in-crowd, beautiful people, haut monde, moneyed class, the wellto-do, the Four Hundred, the upper crust, patrician.

Широко вживане нині позначення представників вищого класу the upper crust 3'явилось у XV столітті, коли в Англії хліб ділили відповідно до статусу - прислуга отримувала пригорілий низ, сім'я їла середину, а гостей вшановували верхівкою або скоринкою (the upper crust) [12].

Поява терміну the Four Hundred відносять до 1889 року, коли світській знаменитості Уорду Макалістеру дали завдання вирішити, кого запросити на століття інавгурації президента Джорджа Вашингтона, і той склав список із читирьохсот людей, яких він вважав справжньою елітою, - crème de la crème. Ще одна фразеологічна одиниця salt of the earth, яка позначає кращих людей суспільства, з'явилася як релігійний символ добра та чистоти.

У сучасному англійському суспільстві соціальна структура змінюється і з`являються нові групи людей, що відображаються у таких номінаціях: meritocracy, new establishment, gliteratti, jet set, NYLON, the Bright Young Things, curled darlings, trustufarian [12].

Інноваційні процеси XXI століття у сфері інформатики, економіки сприяють інтенсивному утворенню нових номінацій назв людей та їх соціальних груп. “Технологічна революція”, як зазначає Ю. А. Зацний, підкреслює і збільшує поділ суспільства на заможних (the haves) та незаможних (the haves-not) [3, с. 77]. Це проявляється в тому, що серед “вищих" і "середніх" класів суспільства виділяються так звані технологічно передові сімї (taffy technologically advanced family).

3 одного боку, в сучасному суспільстві з`являються нові групи людей, які швидко досягли успіху за допомогою інтернет-технологій - millionerd, cneaker millioner, dellionaire. Та водночас дедалі більше людей (downshifters) залишають свою стресову роботу, щоб приділяти більше часу сім ї і жити спокійнішим, простішим життям, виконуючи міні-роботи (mini-jobbers, mini-job staffers).

Безперечно, стрімкий розвиток комп'ютерних технологій призводить до появи нової категорії працівників. Люди, що провадять підприємницьку діяльність тільки за допомогою комп'ютерної техніки, кіберпрацівники мають відповідні найменування: e-entrepreneur, entreprenerd, onine entrepreneur, onentrepreneur, e-retailer, e-cruiter, blogger, blogmaster, blogocrat, flash mobber, e-marketeers, e-envoy, knowledge technologist. Новий елемент е(етимологічно-абревіатурне скорочення слова electronic), за допомогою якого з'явилися численні інновації, людей, залучених до інтернет діяльності, внесено до категорії префіксоїдів. У газеті “Independent" так описують e-lancers - людей, які ведуть підприємницьку діяльність за допомогою комп'ютерної техніки: "E-lancers are internet-enabled home and mobile workers who rely on the internet to organise their work and communicate with colleagues" [14]. Народжується i колективне поняття “інтернетівської еліти” - wired set [3, с. 13].

Зміни у словниковому складі мови відбуваються не тільки завдяки кіберреволюції, а й іншим суспільно-виробничим інноваціям. Як зазначає німецька дослідниця Габрела Штейн, у 90-ті pp. XX ст. серед головних «сфер лексичного росту» перше місце посідала політика, затим - масмедіа та Інтернет, тоді як на початку нового століття інноваційні мовні процеси на лексикосемантичному рівні найактивніше відбуваються в тих галузях, що перебувають під дією таких макросоціальних чинників, як інформаційна революція та пов'язані з нею радикальні зміни у «стилі життя» носіїв: економічні зміни, міжнародний тероризм та боротьба 3 ним, проблеми навколишнього середовища, рівних прав у суспільстві [9, р. 46].

Створення 1993 року Європейського союзу, метою якого було посилити політичну та економічну інтеграцію європейських країн, призвело до появи численних «євронеологізмів». Позначення працівників адміністрації Європейського союзу «еurocrats», які дуже суворо дотримують офіційних законів, відбулося за аналогією від bureaucrat. Людина, що здобула освіту в європейській школі і вважає, що знає все, - eurobrat. На сьогодні членами єврозони (euromembers, $E U$ members $)$ є 27 країн Західної і Східної Європи. Найуспішнішими членами ЄС залишаються 
німці, політики позначають їх як EU-Inlanders або EU-natives [3, с. 86]. Емігрантів, переважно 3 бідних країн, які в пошуках кращого життя подорожують країнами Свропи, називають asylum shoppers (migrants who pass through several countries before applying for asylum in a country that appears to be the most accommodating). "The extent of the racket was revealed last night after a week-long operation targeting the asylum 'shoppers' - so-called because they shop around for better benefit deals between various EU countries" [12].

Через ймовірний вихід Великобританії з Євросоюзу (Brexit) з'явилася низка неологізмів, що відображають суспільний настрій, повязаний 3 політичними подіями в Сполученому Королівстві: Brexiters или Brexiteers (євроскептики, прихильники виходу з Свросоюзу), regrexiteers - ті, хто шкодують про голосування за вихід з СC someone who regrets the vote to leave the EU; bremoaners - британці, які скаржаться щодо виходу з СС. "Call them Bremoaners, or simply people in Brenial; these voters remain passionate in their reluctance for Britain to leave the EU" [15]. Утворення нових назв здійснено за допомогою суфікса -er та словоскладення.

У сучасному світі роль політики в суспільстві й надалі зростає, що пояснюється загальною тенденцією до демократизації та глобалізації усіх сфер суспільства. Лексеми політичного дискурсу ефективні, коли грунтуються на системі ціннісних понять - i загальнолюдських, і національних. 1996 року під час президентських виборів у США утворився термін - soccer moms, що позначає жінок із середнього класу, які витрачають значну частину часу, щоб відвезти своїх дітей на спортивні змагання. Термін-послідовник security moms 3'явився 2004 року, коли велика кількість матусь переймалася безпекою дітей через війну в Ірані та у зв язку з посиленням тероризму.

У Великобританії політичний термін "Worcester woman" вживали під час виборчих кампаній у 1997-му та 2001 роках, апелюючи до офісних працівниць (white collars), яких переважно хвилюють питання якості життя. Часто-густо цю назву відносять до пейоративної, що зображує жінку із споживацькими поглядами, яка може проголосувати за будь-яку партію із високим рейтингом. "Whatever happened to Worcester Woman? The voter credited with ensuring victory for Tony Blair in 1997 was a struggling mother with two children, little interest in politics and the power to ordain the nation's future" [16].

У сучасному американському політичному дискурсі група білих середнього віку працівників з робітничого або нижче середнього класу дістала назву NASCAR dads, бо іiі представникам властиві типові розваги та спортивні уподобання. NASCAR (National Association for Stock Car Auto Racing) - це перегони стандартних машин, а не спеціально змодельованих; подія, що набула величезної популярності у США у 1990-х і нині є другою за популярністю спортивною телевізійною передачею. 2004 року демократи намагалися заволодіти саме голосами цих виборців, яких, за оцінками соціологів, є 45 мільйонів. "Nascar dad is, apparently, the white, heterosexual embodiment of the swing voter in this next election, and a great deal of time and effort and money are being spent trying to hunt the poor guy down" [13].

Становлення і розвиток інформаційної індустрії як сфери виробництва засобів масової комунікації зумовлено розширенням сфери інформаційних потреб суспільства, суспільноекономічним та науково-технічним розвитком, процесами глобалізації системи масової комунікації. За визначенням О. В. Зернецької, глобалізація системи масової комунікації поняття, що активно використовується з кінця ХХ століття, відображає процес трансформації комунікаційної системи, такої трансформації, яка пов язана 3 утворенням більш широкої мережі комунікаторів, що обслуговуються й покриваються на більшому інформаційному просторі єдиною, але розгалуженою системою засобів масової комунікації [4, с. 44].

Працівники засобів масової інформації, з одного боку, - для вираження інтересів сучасного суспільства, а з другого - для ефективного впливу на масову свідомість, опановують технологічно-передові засоби і в результаті дістають нові професійні назви: cyber-journalists, bloggers, webcasters.

3'являється дедалі більше людей, які працюють удома, використовуючи комп'ютер i телефон (teleworkers). I навіть священики (televangelists) регулярно пропагують віру, звертаючись до людей через екран. Неологізми утворюються за допомогою префіксоїда tele- (from Greek combining form of tele "far off, afar, at or to a distance) [14]. Назви осіб за професією виділяються зі всієї маси новостворених лексичних одиниць, бо вони називають особу за соціально найбільш значущою ознакою - за їі місцем і роллю в суспільному виробництві. 
У світі цифрових технологій стали популярними метафори hive mind та swarm behaviour. Динамічний та набутий популярності Інтернет уособлює колективний розум, він асоціюється 3 вуликом, мурашником, роєм, зграєю. Люди, залучені до бізнесу, можуть характеризуватися як marketing slime (slime - багно, каламуть, слиз) та salescritters продавці комп'ютерів (де critter - тварина, тварюка). Тим часом безпорадних людей, які телефонують, безкінечно запитуючи про технічні проблеми, відповіді на які є зазвичай очевидними, називають dead end users (буквально користувачі, які зайшли в глухий кут). Бажання користувачів олюднити комп'ютер простежуємо в тому, що свого найкращого друга користувачі згадують як square-headed girlfriend / boyfriend, тобто як свого друга чи подругу [7]. У наведених прикладах спостерігаємо явище персоніфікації.

Слід зазначити, що в умовах сучасного етапу науково-технічної революції різні галузі пов'язані з розв язанням проблеми втручання людства у природу. Наприкінці XX - на початку XXI століть сфера екології виявилась одним із головних постачальників неологізмів у англійській мові у зв'язку з новими тенденціями і напрямами соціально-екологічного розвитку. Зміни в суспільстві стосовно розв 'язання екологічних проблем потребують уточнення, поглиблення наявних наукових понять та зумовлюють утворення нових мовних одиниць для позначення сучасних реалій життя. Дедалі більша кількість назв із префіксоїдом есо- свідчить про надзвичайну актуальність екологічних проблем у світі і зростання екологічної свідомості громадян різних країн. Крім екотуристів (ecotourists), на захист навколишнього середовища стають екоохоронці (ecoguards), екоспоживачі (eco-consumers), екодіти (eco-kids), ековоїни (ecowarriors) i навіть екофеміністки (eco-feminists). Екстремальні активісти (eco-terrorists) вдаються до численних злочинів (окрім убивства) заради захисту тварин та екосистеми. Такі терористичні акти дістали назву, утворену за допомогою телескопії - ecotage. "Acts of ecoterrorism, also known as ecotage (a combination of the prefix "eco" and the word "sabotage"), attack people or things that threaten the environment or the wildlife it supports. Eco-terrorists, or "ecoteurs," as they're sometimes known, profess to value all life, so they don't strike to kill, but instead use scare tactics like arson to iscourage their enemies" [10].

Висновки. Інноваційні найменування засвідчують, що зміни в соціо-політичній сфері суспільного життя людини сприяють інтенсивному утворенню нових номінацій назв людей та їх соціальних груп, бо інтерес до людини як до центру Всесвіту та до людських потреб як детермінуючих різні види людської діяльності $є$ одним з головним принципів світогляду людства в сучасному світі. Серед найпродуктивніших способів утворення найменувань людини, що народжуються внаслідок суспільних змін, виділимо афіксацію та словоскладення.

Варто зазначити, що словотворення не обмежується лише активною участю в поповненні словникового складу наявними мовними ресурсами, а й активно включається у репрезентацію функціонування когнітивних механізмів людської свідомості, здійснюючи пошук тих елементів та їх комбінацій у своєму арсеналі, які найкраще сприяють реалізації номінативних і когнітивних механізмів англійської мови.

\section{ЛІТЕРАТУРА}

1. Арутюнова Н. Д. Язык и мир человека. - М.: Языки русской культуры, 1999. - 896 с.

2. Городецька О. В. Національні-марковані концепти в британській мовній картині світу ХХ століття: автореф. дис. на здобуття наук. ступеня канд. філол. наук: спец. 10.02.04 «Германські мови»; Київськ. нац. ун-т імені Тараса Шевченка. - К., 2003. - 20 с.

3. Зацний Ю. А. Сучасний англомовний світ і збагачення словникового складу. - Л.: ПАІС, 2007. -228 с.

4. Зернецька О. В. Глобальний розвиток систем масової комунікації і міжнародні відносини. - К.: Освіта, 1999. - $351 \mathrm{c}$.

5. Карасик В. И. Язык социального статуса / Владимир Ильич Карасик. - М.: Ин-т языкозн. РАН; Волгоградск. гос. пед. ин-т, 1992. - 330 с.

6. Левицький А. Е. Етнономінації у дзеркалі міжкультурної комунікації: [монографія] / А. Е. Левицький, Ю. В. Святюк. - К.: Логос, 2011. - 192 с.

7. Скибицька Н. В. Переносні значення слів як джерело виникнення нової комп'ютерної лексики у сучасній англійській мові [Електронний ресурс] // Мовні і концептуальні картини світу. - 2011. - Режим доступа до ст.: http://www.philolog.univ.kiev.ua/library/zagal/Movni_i_konceptualni_2011_38/484_488.pdf

8. Уфимцева А. А. Лексическое значение. Принципы семиологического описания лексики. - М.: Наука, 1986. - 240 с.

9. Stein G. Better Words. Evaluating EFL Dictionaries / G. Stein. - Exeter : University of Exeter Press, 2002. - 246 p. 
10. HowStuffWorks. (2010). How Eco-terrorism Works. Retrieved 2010 from https://science.howstuffworks.com/environmental/green-science/eco-terror3.htm

11. Online Etymology Dictionary. Retrieved 2015 from www.etymonline.com.

12. The Free Dictionary by Farlex [Електронний ресурс]. - Режим доступу до сайта: www.thefreedictionary.com

13. The New York Times (2004). The New Electoral Sex Symbol: Nascar Dad. Retrieved January 18, 2004 from https://www.nytimes.com/2004/01/18/weekinreview/the-new-electoral-sex-symbol-nascar-dad.html

14. The Independent. (2001). The fluid new age of the e-lancer is upon us. Retrieved May 1, 2001from https://www.independent.co.uk/voices/commentators/the-fluid-new-age-of-the-e-lancer-is-upon-us-5364887.html

15. The Telegraph (2016). A Stop Brexit party would never work. But politicians will still try to pander to those in 'Brenial'. Retrieved Ocrober 27, 2016 from https://www.telegraph.co.uk/news/2016/10/27/a-stopbrexit-party-would-never-work-but-politicians-will-still/

16. The Telegraph (2014). Worcester Woman lives - and she could settle Ed Miliband's fate. Retrieved November 5, 2014 from https://www.telegraph.co.uk/news/politics/ed-miliband/11208812/WorcesterWoman-lives-and-she-could-settle-Ed-Milibands-fate.html 